\title{
ANATOMICAL STUDIES ON THE VENOUS DRAINAGE OF THE INTESTINAL TRACT OF THE DONKEY (EQUUS ASINUS)
}

\author{
M.A. El-Ayat. Y. R. Wally. F. A. El-Nady. S. H. El-Bably
}

\begin{abstract}
The venous drainage of the intestine was carried out on 8 apparently healthy adult donkeys. The age and sex of the animals were not considered in this study. The venous drainage of the intestinal tract were done by the ordinary routine methods as well as the cast preparation. The venous blood of the intestinal tract is mainly achieved by the $V$. Portae through its peripheral tributaries. In addition to the caudal rectal of the internal iliac vein. A comprehensive description of the origin, course and distribution of the veins of the intestinal tract were studies. The results obtained were discussed with those of other authors in the horse and other domestic animals.
\end{abstract}

Key words: donkey-intestine-veins.

\section{INTRODUCTION}

Donkeys are cheaper animal and very useful in the farms and in dissecting rooms for teaching purposes. The anatomy of the donkeys especially the study of the blood vessels attracted the attention of many investigators, in order to establish an independent base for that animal.

The venous drainage of the intestinal tract has been described by Horowitz and Venzke (1966) and Yadm et al (1992) in the goat, Heath (1968) in the sheep, Aly et al (1980) and Mustafa et al (1986) in the camel, Koch and Ghoshal (1981) in the domestic animals and Kalt and Stump (1993) in canine. 
Therefore, the present study is carried out on the venous drainage of the intestinal tract to add some anatomical knowledge to what have been recorded previously and to emphasis the anatomical differences between donkey and other animals.

\section{MATERIAL AND METHODS}

The research was conducted on 8 apparently healthy adult donkeys collected from the Giza Governorate. The age and sex of the animals were not considered in this study.

The animals were anaesthetized and bled through the carotid cannulation. The vessels were thoroughly washed with warm saline solution. The specimens were injected with formalin mixture solution of $10 \%$ formalin, $4 \%$ phenol and 1\% glycerin for fixation (Tomsett and Wakeley, 1965).

For demonstrating the intestinal veins, the specimens were prepared and injected with 60\% gum milk Latex (Hildebrand, 1968) Colored blue with ROTRING® ink. The root of injection directly through the portal or splenic vein and the caudal vena cava.

The animals were left in a cold room for about 48-72 hours before the routine dissection was performed.

Nomenclature in this work was adopted according to the Nomina Anatomica Veterinaria (N.A.V) 2005.

\section{RESULTS}

The venous blood of the intestinal tract is mainly achieved by the portal vein through its peripheral tributaries. In addition to the caudal rectal of the internal iliac vein. 
V. Portae (Fig.1, 2/1, 3/11):

The portal vein was a huge trunk which received the blood from the gastrointestinal tract and spleen. It is formed beneath the caudal vena cava and just caudal to the pancreas. It traversed through the portal ring of the pancreas to gain the portal fissure of the liver. Its peripheral branches are the gastroduodenal, cranial mesenteric, caudal mesenteric, splenic and pancreatic branches.

\section{V. gastroduodenalis (Fig.1, 2/7 \& 3/14):}

The gastro-duodenal vein originated from the portal vein just ventral to the body of the pancreas. It passed to the dorsal curve of the cranial part of the duodenum, where it gave off the cranial pancreaticoduodenal vein and continued as right gastroepiploic vein.

\section{a-V. Pancreatico-duodenalis cranialis (Fig.1/8 \& 3/15):}

The cranial pancreatico-duodenal vein proceeded caudally on the dorsal aspect of the cranial part of the duodenum, being partially covered by the right lobe of the pancreas. It drained the cranial part of the duodenum, cranial duodenal flexure and the initial part of the descending duodenum.

\section{b- V. gastroepiploica dextra(Fig.1/9 \& 3/16):}

The right gastroepiploic vein represented the direct continuation of the gastroduodenal vein. It crossed the Pars cranialis duodeni beneath the body of the pancreas. It passed along the greater curvature of the stomach then turned left and caudally through the greater omentum. It terminated by anastomosing with the left gastroepiploic vein. Along its course it gives off 4-6 radicals to the pylorus and cranial part of the duodenum. 


\section{V. mesenterica cranialis (Fig.1, 2/5 \& 3, 4/1):}

The cranial mesenteric vein was the largest radical of the portal vein. It detached from the right side of the portal vein, being covered by the right lobe of the pancreas. It proceeded craniovenytrally with its homonymous artery, detaching the caudal pancreatico-duodenal vein, jejunal trunk and then continued as an ileocolic vein near the ileocecal junction.

\section{a- V. pancreatico-duodenalis caudalis (Fig.2/8 \& 4/2):}

The caudal pancreatico-duodenal vein was the first tributary of the cranial mesenteric vein. It proceeded cranially being enclosed by the mesoduodenum. It divided into branches, draining the second half of the descending duodenum, caudal duodenal flexure and the initial part of ascending duodenum.

\section{b- Truncus jejunalis (Fig.2/9, 3/2, 4/3 \& 5, 6/1):}

The jejunal trunk is a stout but short trunk. The number of the jejunal veins ranged from 16-19 radicals. They leave their parent trunk and ran sparsely through the mesojejunum in a radiating manner towards the jejunal convolution. Each jejunal vein divided into two smaller Rami, which anastomosed with those of the adjacent vessel forming primary venous arches. These series of anastomotic arches are the pattern for most of the jejunal veins. From the convexity of the primary arches, fine branches detached and proceeded toward the small intestine and forming another series of secondary arches, from which fine branches are passed to the wall of the jejunum.

The first jejunal vein (fig.4/4, 5/1') arose with the second one by a common stem in $50 \%$ of cases. It released two slender branches that drain the ascending duodenum as well as the duodenojejunal flexure. 
The third, fourth, fifth and sixth jejunal veins (Fig.5/3 , 4`,5 ,6`) arose from the jejunal trunk by a common stem extending ventrally towards the intestinal convolutions then behave the same pattern of division. The seventh and eighth jejunal veins (Fig.5/ 7`, $8^{\prime}$ ) arose by a common trunk in $30 \%$ of cases.

The rest of the jejunal veins (fig.5/9`-18`) arose separately from the jejunal trunk. The last jejunal vein (fig. 6/2) leaved its origin and anastomosed with the ileal vein forming primary venous arches, which drain the ileum and the terminal part of the jejunum through several minute branches.

\section{c- V. ileocolica (Fig.2/11 \& 3/4):}

The ileocolic vein could be considered as the direct continuation of the cranial mesenteric vein after detaching the jejunal trunk. It gave off an ileal, medial cecal, lateral cecal and continued as the colic branch.

\section{V. ilei (Fig.2/13, 3/6 \& 6/4):}

The ileal vein originated from the ventral aspect of the ileocolic vein, it ran caudoventrally for a short distance to gain the mesenteric border of the ileum. It gave rise to 11-13 smaller branches that draining the ileum and terminated by anastomosing with the last jejunal vein, forming primary venous arches.

\section{V. cecalis medialis (Fig.2/12, 3/5 \& 6/3):}

The medial cecal vein originated from the ileocolic vein and accompanies its homonymous artery. It passed cranioventrally toward the medial cecal band and continued to the apex of the caecum where it anastomosed with the lateral cecal vein. It detached numerous fine branches to the cecal tissue as well as the cecal lymph nodes. 


\section{V. cecalis lateralis (Fig.2/14, 3/7 \& 7/1):}

The lateral cecal vein arose from the ileocolic vein opposite to the ileocecal orifice. It pursued a straight course along the lesser curvature of the cecum then turned to the right between the right ventral colon and the body of the caecum. It continued on the lateral cecal band toward the cecal apex where it anastomosed with the medial cecal vein. During its course it detached the vein of the arch.

The vein of the arch (fig.7/2) leaved the lateral cecal vein along the lesser curvature of the caecum and then continued to the lateral surface of the right ventral part of the great colon. It detached 2-3 fine branches to the base of the caecum.

\section{R. colicus (Fig.2/15, 3/8 \& 8 /1):}

The colic vein could be considered as the direct continuation of the ileocolic vein after releasing the lateral cecal vein. It proceeded along the dorsomedial band of the ventral colon to gain the pelvic flexure where it anastomosed with the right colic vein. Along its course it detached several communicating branches (Fig.8/3) that join those of the right colic vein especially at the sternal and diaphragmatic flexures. At the mesenteric border the colic vein released several fine branches to the colonic tissue of the ventral colon, sternal flexure as well as the colic lymph nodes.

\section{V. mesenterica caudalis (Fig.1, 2/4, 3/13, 10/1):}

The caudal mesenteric vein is a small radical originated from the portal vein. It gave rise to the middle colic vein then passed caudoventrally for about 4-6 cm through the mesocolon, detaching the left colic vein and continued as the cranial rectal vein. 


\section{a- V. colica media (Fig.2/16\& 9/1):}

The middle colic vein arose from the caudal mesenteric vein infront of the transverse colon. It proceeded caudally, and then continued within the descending mesocolon to the initial part of the small colon. It terminated by anastomosing with the left colic vein. It drained the transverse colon and the initial part of descending colon.

\section{V. colica dextra (Fig.3/10 \& 8, 9/2):}

The right colic vein arose from the middle colic vein. At first it proceeded cranially along the ventral tenia of the right dorsal colon, and then continued caudally along the left dorsal colon. It terminated by anastomosing with the colic branch at the pelvic flexure. It received short communicating branches (Fig.8/3) derived from the colic vein especially at the sternal and disphragmatic flexure. It drained the dorsal parts of the ascending colon.

\section{b- V. colica sinistra (Fig.10/2, 3):}

The left colic vein originated from the caudal mesenteric vein, it represented by two main branches. The cranial branch (Fig.10/2) passed cranioventrally within the mesocolon for about $1.5-2 \mathrm{~cm}$ and divided into two branches which anastomosed together and with those of middle colic vein forming primary and secondary venous arches. Finally, it terminated by anastomosing with the middle colic vein at the cranial third of the descending colon. It detached numerous branches to the wall of the cranial third of descending colon. The caudal branch (Fig.10/3) descended in the mesocolon and behaved the same division like the cranial branch. It anastomosed with the branches of the cranial rectal vein forming primary and secondary arches. The latter arcades gave off minute branches that drain the middle third of the descending colon. 


\section{c- V. rectalis cranialis (Fig.10/4 \& 11/1):}

The cranial rectal vein could be considered the direct continuation of the caudal mesenteric vein after detaching the left colic vein. It proceeded caudoventrally within the mesocolon and mesorectum, detaching 5-6 short branches, which are distributed to the caudal third of the descending colon, peritoneal part of the rectum and rectal ampulla and terminated near the anus by anastomosing with the caudal rectal branch of the ventral perineal vein..

\section{V. rectalis caudalis (Fig.12/4):}

The caudal rectal vein arose from the ventral perineal vein. It ascended along the lateral surface of the rectal ampulla and terminated near the anus by anastomosing with the branches of the cranial rectal vein.

\begin{tabular}{|c|c|c|}
\hline a- & spleen & q- left ventral colon \\
\hline b- & stomach & r- pelvic flexure \\
\hline c- & right lobe of the liver & s- left dorsal colon \\
\hline d- & kidney & t- diaphragmatic flexure \\
\hline e- & pancreas & U- ri2ht dorsal colon \\
\hline f- & cranial part of the duodenum & $v-$ transverse colon \\
\hline g- & cranial duodenal flexure & w- descending colon \\
\hline h- & descending duodenum & $x-$ peritoneal part of the rectum \\
\hline i- & caudal duodenal flexure & $y-\quad$ anal canal \\
\hline j- & ascending duodenum & z- anus \\
\hline k- & duodenojejunal flexure & ag- adrenal gland \\
\hline l- & jejunum & dp- diaphragme \\
\hline m- & ileum & cc- cecocolic ligament \\
\hline n- & ceacum & mc- mesocolic ligament \\
\hline$n^{\prime}-$ & cecal base & mj- mesojejunum \\
\hline n"- & cecal body & md- mesodescending colon \\
\hline$n^{\prime \prime \prime}-$ & cecal apex & ic- ileocecal ligament \\
\hline o- & right ventral & pa- primary arches \\
\hline p- & sternal flexure & sa- secondary arches \\
\hline
\end{tabular}

$\overline{\text { Kafrelsheikh Vet. Med. J. Vol. } 6 \text { No. } 1 \text { (2008) }}$ 




Fig. (1): A photograph showing the portal vein \& its tributaries.

1- V. Portae.

2- V. Lienalis.

3- V. gastrica sinistra.
4- V. mesenterica caudalis.

5- V. mesenterica cranialis.

6- Rami pancreatici.
7- V. gastroduodenalis.

8- V. pancreaticoduodenalis cranialis.

9- V. gastroepiploica dextra.



Fig. (2): A photograph showing the tributaries of the portal and cranial mesenteric veins (latex cast).

Kafrelsheikh Vet. Med. J. Vol. 6 No. 1 (2008) 


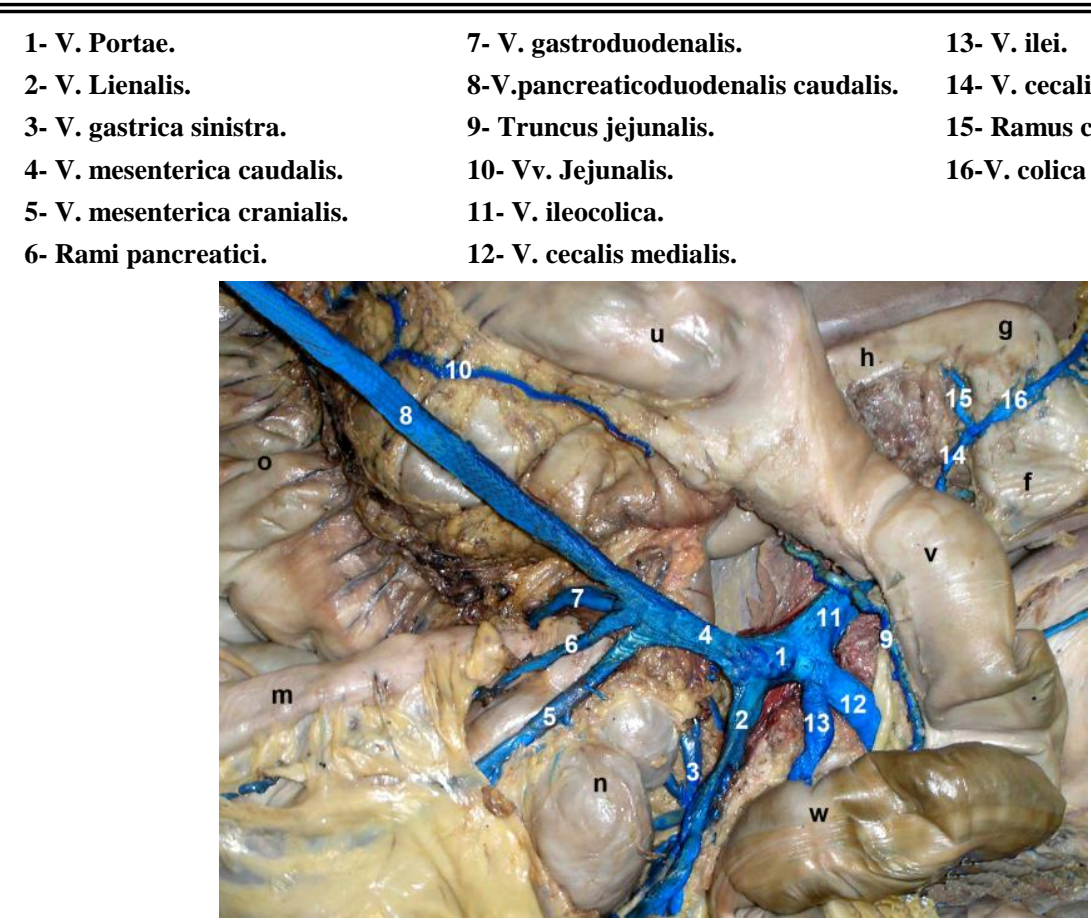

Fig. (3): A photograph showing the main branches of cranial mesenteric vein.

1- V. mesenterica cranialis.

2- Truncus jejunalis.

3- Vv. Jejunalis.

4- V. ileocolica.

5- V. cecalis medialis.

6- V. ilei.
7- V. cecalis lateralis.

8-Ramus colicus.

9- V. colica media.

10- V. colica dextra.

11- V. Portae.

12- V. Lienalis.
13- V. mesenterica caudalis.

14- V. gastroduodenalis.

15-V.pancreaticoduodenalis cranialis.

16- V. gastroepiploica dextra.




Fig. (4): A photograph showing the main branches of cranial mesenteric vein.
1- V. mesenterica cranialis.
4- Vv. Jejunalis.
6- V. cecalis medialis.
2- V. pancreaticoduodenalis caudalis.
$4-1^{\text {st }}$ jejunal vein.
7- V. ilei.
3- Truncus jejunalis.
5- V. ileocolica.

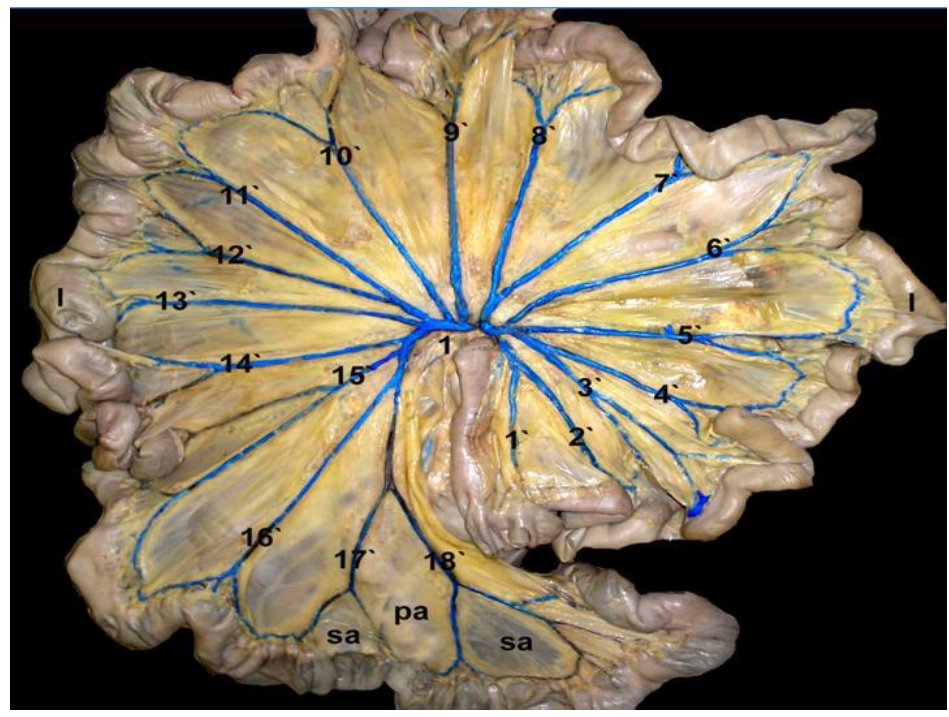

Fig. (5): A photograph showing the pattern of distribution of the jejunal veins. 1-Truncus Jejunalis. 1' 18 - Vv. Jejunalis.

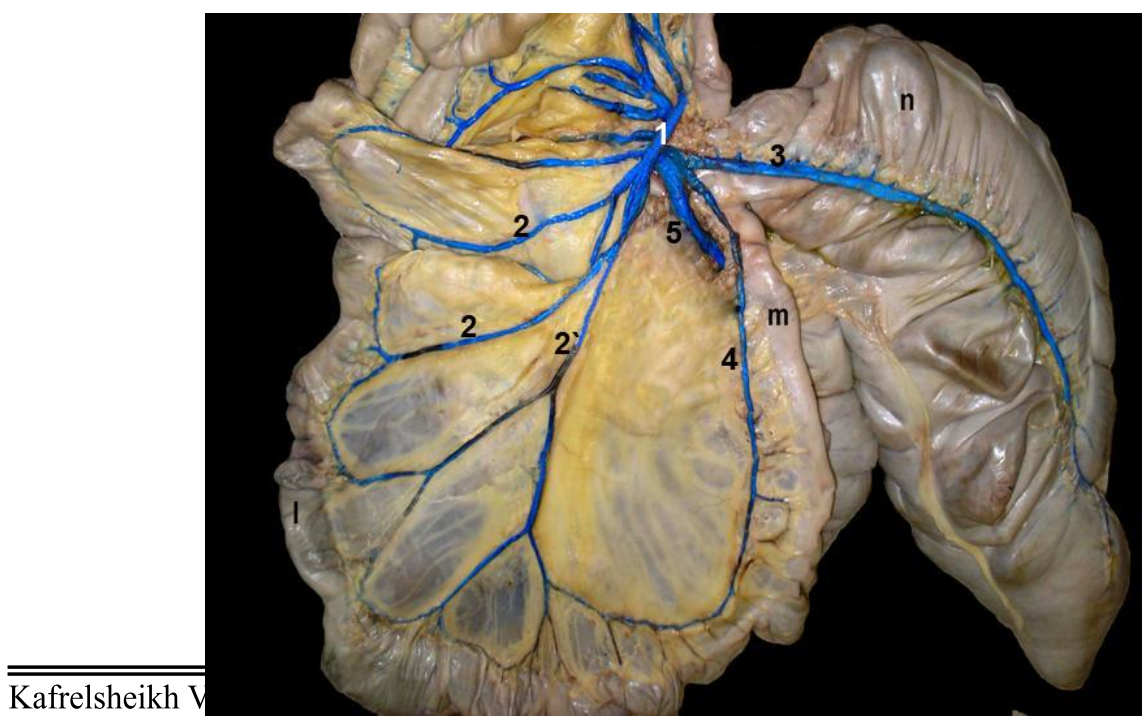


Fig. (6): A photograph showing the jejunal trunk, medial cecal, ileal and colic veins.

1- Truncus Jejunalis.

2- Vv.jejunalis.
2'- Last jejunal vein.

3- V. cecalis medialis.
4- V. ilei.

5- Ramus colicus.



Fig. (7): A photograph showing the lateral cecal vein \& the vein of the arch. 1- V. cecalis lateralis. 2- the vein of arch.




Fig. (8): A photograph showing the venous drainage of the ascending colon.
1- Ramus colicus.
2- V. colica dextra.
3- communicating branches.



Fig. (9): A photograph showing the distribution of the middle colic vein. 1-V. colica media. 2-V. colica dextra.




Fig. (10): A photograph showing the branches of the caudal mesenteric vein.

1- V. mesenterica caudalis.

2,3 - V. colica sinstra.

4- V. rectalis cranialis.



Fig. (11): A Photograph showing the distribution of the cranial rectal vein. 1- V. rectalis cranialis.




Fig. (12): A Photograph showing the caudal rectal vein.

1- pudenda interna.

2- perinealis ventralis.
3- V. clitoridis.

4- V. caudalis rectalis.

\section{DISCUSSION}

The present study revealed that, the portal vein gave rise to pancreatic branches, gastroduodenal, splenic, cranial mesenteric and caudal mesenteric veins. Such results were in agreement with that described by Wilkens and Munster (1981) in the domestic animals.

The gastroduodenal vein in the donkey arose from the portal vein ventral to the body of the pancreas. Similar finding was given by $\mathbf{O m a r}$ (1978), Wally (1986) and Mustafa et al., (1986) in the camel. On the other hand, it was detached from the left branch of the portal vein in the ox (Koch and Ghoshal, 1981), goat (Scupin, 1960 and Horowitz and Venzke, 1966) and dog (Vitums, 1959).

The gastroduodenal vein gave rise to the cranial pancreaticoduodenal branch then continued as right gastroepiploic vein. In this respect Wilkens and Munster (1981) in all domestic animal, Koch and Ghoshal (1981) in equines, bovines and carnivores and Omar (1978), Wally (1986) and Mustafa et al., (1986) in the camel, stated that the gastroduodenal vein gave off to the right gastric, cranial pancreaticoduodenal veins and then continued as the right gastroepiploic vein.

The present study, observed the presence of a cranial and a caudal pancreatico-duodenal veins. On the other hand, Sisson and Grossman 
(1969) in the horse and Omar (1978) in camel observed a single pancreatico-duodenal vein.

The current study revealed that, the cranial mesenteric vein gave off the caudal pancreatico-duodenal, jejunal trunk and then continued as the ileocolic vein. While it gave off the caudal pancreatico-duodenal vein and divided into jejunal and ileocolic veins, as stated by Bradley and Graham (1946) and Sisson and Grossman (1969) in the horse, McLeod (1958), Raghavan and Kachroo (1964), Heath (1968) and Koch and Ghoshal (1981) in ruminants, Schively (1984), Kalt and Stump (1993) and Evans et al., (1993) in the dog, Omar (1978), Aly, Omar and Mustafa (1980), Wally (1986) and Mustafa et al (1986) in the camel, and Koch and Ghoshal (1981) in the pig.

Concerning, the origin of the caudal pancreatico-duodenal vein it was detached from the cranial mesenteric vein in the donkey. Similar results were mentioned by Koch and Ghoshal (1981) in ruminants. However in the camel, Wally (1986) and Mustafa et al (1986) traced that it was a branch from the first jejunal vein.

The present investigation revealed the number of the jejunal veins was ranged from 16-19 in the donkey and they arose together by a common jejunal trunk from the cranial mesenteric vein. In this respect, their number were ranged from 10 to 14 in the horse (Koch and Ghoshal, 1981), 7 to 15 in the dog (Vitums, 1959 and Evans et al., 1993 ), 4 in the pig (Hapke, 1957 ), 25 to 35 in goats (Scupin, 1960) and 5 in the camel (Omar, 1978, Wally, 1986 and Mustafa et al. 1986).

Regarding the distribution of the first jejunal vein in the donkey, it gave 2 to 3 branches that supplied the ascending duodenum and 
duodenuojejunal flexure. Similar finding was recorded in the camel by Omar (1978).

In agreement with the statement of McLeod (1958) in the ox, May (1970) in sheep, Koch and Ghoshal (1981) in the goat and Omar (1978) in the camel, the ileocolic vein was considered as direct continuation of the cranial mesenteric vein.

The present finding revealed that, the colic branch was considered the direct continuation of the ileocolic vein. On the other hand, Koch and Ghoshal (1981) in the horse recorded that, the ileal vein is the direct continuation of the ileocolic vein after releasing the medial and lateral cecal veins. Omar (1978), Wally (1986) and Mustafa et al. (1986) in the camel considered that the cecal vein is the direct continuation of the ileocolic vein.

The current investigation observed the presences of only one ileal vein which originated from the ileocolic vein, proceeded along the mesenteric border of the ileum and anastomosed with the last jejunal vein. Such result was confirmed by Koch and Ghoshal (1981) in the horse, pig and dog, (Maala and Sack, 1983) in the ox. However, Omar (1978) and Mustafa et al (1986) revealed the presence of two unequal mesenteric ileal veins in the camel.

The present work revealed that the lateral and medial cecal veins were released separately from the ileocolic vein. Similar result was reported by Koch and Ghoshal (1981) in the horse. However the ileocolic gave off only one cecal vein in the pig, ox, sheep, goat (Koch and Ghoshal, 1981) and in camel (Wally, 1986). 
In agreement with Koch and Ghoshal (1981) in the horse the present study revealed that, the lateral cecal vein gave rise to the vein of the arch which passed along the lateral band of the right ventral colon.

Regarding the colic branch, the present study, considered it as the direct continuation of the ileocolic vein. On the other hand, Sisson and Grossman (1969) recorded two colic veins instead of one in the horse. Maala and Sack (1983) denoted 3 colic branches in the ox, Wally (1986) recorded from 4 to 6 colic branches in the camel.

The origin of the caudal mesenteric vein from the portal vein in the donkey, simulating that recorded by Koch and Ghoshal (1981) in the horse and pig. On the other hand, it was originated from the cranial mesenteric vein in the ox, sheep, goat (Koch and Ghoshal, 1981), dog (Evans et al. 1993) and camel (Wally, 1986).

In accordance with Koch and Ghoshal (1981) and Wilkens and Munster (1981) in the horse and ruminants, the middle colic vein was given from the caudal mesenteric vein. While in the dog, it was detached from the ileocolic vein (Vitums, 1959) and from the right colic in the camel (Wally, 1986).

The present work revealed that, the right colic vein was originated from the middle colic vein. On the other hand, it was detached from the cranial mesenteric vein in ruminants (Koch and Ghoshal, 1981) and from the caudal mesenteric vein in the camel (Mustafa et al. 1986).

In the present study, communicating branches were observed between the colic branch and right colic vein at the sternal and diaphragmatic flexure. In this respect, Koch and Ghoshal (1981) 
observed an anastomotic branch connecting the right colic with the caudal mesenteric vein via the middle colic vein in the horse.

The current work revealed that, the left colic vein was originated from the caudal mesenteric vein. Similar finding were mentioned by Koch and Ghoshal (1981) in the horse. On the other hand, Vitums (1959) traced its origin from the ileocecocolic vein in dog. However, Wilkens and Munster (1981) in horse, ruminants and Wally (1986) in the camel, stated that the left colic vein was considered the direct continuation of the caudal mesenteric vein.

Regarding the cranial rectal vein, the current work revealed that, it was considered as the direct continuation of the caudal mesenteric vein. While in the ruminants (Koch and Ghoshal, 1981), dog (Evans et al. 1993) and camel (Omar, 1978 and Wally, 1986) it considered as the direct continuation of the left colic vein.

The present work revealed that, the caudal rectal vein was detached from the ventral perineal vein. Similar to that mentioned by Habel (1953) in the dog, Koch and Ghoshal (1981) in the horse and Saber (1979) and Wally (1986) in the camel. On the other hand, Koch and Ghoshal (1981) reported its origin from the caudal gluteal vein in the pig, from the internal pudendal vein in the ox and from the dorsal perineal vein in the goat.

\section{REFERENCES}

- Aly, M.A.; A.M. Omar and M.S. Moustafa (1980): Some anatomical studies on the mesenteric veins of one humped camel (Camelus dromedaries ). Egypt. J. Anat., Vol. 3, No. 1, 129-133. 
- Bradley and T. Graham (1946): The topographical anatomy of the horse ( $2^{\text {nd }}$ ed. ) thorax and abdomen. W. Green and Son, Limited, Edinburgh.

- Evans, H.E. (1993): Miller's Anatomy of the dog. $3^{\text {rd }}$ ed. W. B. saunders co. philadelpia.

- Habel,R.E.(1953): The perineum of the mare.Cornell Vet.,43,250-278.

- Hapke, H. J. (1957): Die Pfortader des Schweines Hannover, Tierärztl. Hochsch., Diss.

- Heath, T. (1968): Origin and Distribution of the portal blood in sheep. Am. J. Anat., 122, 95-106.

- Hildebrand, M. (1968): Anatomical preparation. University of California Press. Berkeley and Los Angeles, California.

- Horowitz, A. and W. G. Venzke (1966): Distribution of the blood vessels to the postdiaphragmatic digestive tract of the goat. Celiac trunk-Gastroduodenal and splenic tributaries of the portal vein. Am. J. Vet. Res., Vol. 27, No. 120, 1293-1315.

- Kalt, D. J. and J. E. Stump (1993): Gross Anatomy of the canine portal vein. Anat. Histol. Embryl., 22, 191-197.

- Koch, T. and N.G. Ghoshal (1981): The Venous Drainage of the Domestic Animals. W.B. Saunders Co. Philadelphia Toronto Sydney.

- Maala, C.P. and W.C. Sack (1983): The Venous Supply to the Ileum, Cecum and Proximal Loop of the Ascending colon in the Ox. Zbl. Vet. Med. C. Anat. Histol. Embryol., 12, 154-166 (1983 ).

- May, N.D.S. (1970): The Anatomy of the sheep. $2^{\text {nd }}$ Ed. University of the Queensland Press St. Laucia, Brisbane, Queensland. 
- Mcleod, W. (1958): Bovine Anatomy. $2^{\text {nd }}$ ed. Burgess Publishing Co. Minneapolis, Minnesata.

- Moustafa, M.S.; S.M. Abu-Zaid; S.M. El-Nahla and Y.R. Wally (1986): Some Anatomical observation on The Venous Drainage of the Intestinal Tract of The One-Humped Camel. Alex. J. Vet. Sci., Vol. 2, No. 2, 57-70.

- Nomina Anatomica Veterinaria (2005): $5^{\text {th }}$ ed. World Associstion of Veterinary Anatomists. Gent.

- Omar, A.M. (1978): Some anatomical studies on the portal vein of the one humped camel (Camelus dromedaries). M.V.Sc. Thesis. Zagazig Univ.

- Raghavan, D. and P. Kachroo (1964): Anatomy of the ox. $1^{\text {st }}$ ed. Indian councial of Agriculture Research, New delhi.

- Schively, M. J. (1984): Veterinary Anatomy. $3^{\text {rd }}$ ed. Texas A \& M. Univ., Press, College station.

- Scupin, E. (1960): Blutgefassversorgung der Verdanungs-organe und Bauchspecicheldrüse einsliesslich Leber, milk. Hannover, Tierarztl. Hochsch. Diss.

- Simoens, P.; N.R. DE Vos and H. Lauwers (1984): Illustrated Anatomical Nomenclature of the venous system in the domestic animals. Medelel. Fac. Diergenesk. Rijks Univ. Gent, 25, Nr. 1-2.

- Sisson, S. and J.D. Grossman (1969): The anatomy of the domestic animals. $4^{\text {th }}$ edition, W. B. saunders co. Philadelphia and London.

- Tomsett, D.H. and C. W.Wakeley (1965): Anatomical Techniques. $1^{\text {st }}$ Edition. E \& Living Stone Ltd. Edinburgh and London. 
- Vitums, A. (1959): Porto systemic communication in the dog. Acta Anat., 39, 271-299.

- Wally, Y.R. (1986): Some anatomical observation on the intestinal tract of the one humped camel (Camelus-dromedarius). Thesis, M.V. Sc., Cairo Univ.

- Wilkens, H. and W. Münster (1981): The circulatory system. In Nickel, Scummer and Seiferle Lehrbuch der Anatomic Haustiene vol. 3. Verlag Paul Parey. Berlin and Hamburg.

- Yadm, Z., M. Gad and G. Ragab (1992): Venous drainage of the gastrointestinal tract in the goat.Vet. Med.J., Vol. 40, No. 3: 129-130.

$$
\begin{aligned}
& \text { در اسات تثريحية على الصرف الوريدى للأمعاء في الحمار } \\
& \text { د./ ملحت العياط ، د./ياسر والمي ، د./فونى النادى ، د./سعاح البابلى }
\end{aligned}
$$

نم دراسة الصرف الوريدي للأمعاء على عدد ثمانية من الحمير و قد نم تتبع المنشأ و طريقة

$$
\text { توزيع كل وريد بعد معالجتها بمحلول مطاطي ملون و عمل قالب لها. }
$$$$
\text { وقد تبين إن الصرف الوريدى يتم عن طريق ثلأثنة اوعية رئيسية هى الوريد المساريقي الأمامي و }
$$$$
\text { الخلفي و كذا المعدى العجفى بالإضافة إلي الوريد المستقيمي الخلفي. }
$$

هذا و قد نوقتت النتائج التي تم الحصول عليها مع مثيلاتها في الحيوانات الأليفة الأخرى، كما

$$
\text { استخدمت المصطلحات التشريحية البيطرية الدولية لسنة } 2005 .
$$


